\title{
Opsoclonus Myoclonus Ataxia Syndrome in the Setting of COVID-19 Infection
}

Priyank Bharatkumar Shah, MD, DM, and Soaham Dilip Desai, MD, DM

Neurology ${ }^{\circledR}$ 2021;96:33. doi:10.1212/WNL.0000000000010978

A middle-aged man presented with imbalance and involuntary jerky movements of the body 3 weeks after initial recovery from coronavirus disease 2019 (COVID-19) lung infection, diagnosed by positive high-resolution CT thorax (COVID Reporting and Data System 5) and reverse transcription PCR (RT-PCR) from nasal swab. He had opsoclonus, cortical myoclonus, and symmetric cerebellar ataxia of speech, limbs, trunk, and gait on examination ${ }^{1}$ (video 1). His MRI brain with contrast, CSF examination, HIV, Venereal Disease Research Laboratory, autoimmune, and paraneoplastic panel (including anti-GAD, antinuclear antibodies, antineutrophil cytoplasmic antibodies, anti-Hu, anti-Yo, anti-Ri, anti-amphiphysin, anti-PNAM2$\mathrm{Ma} 2 / \mathrm{Ta}$ antibodies), metabolic functions (hemogram, hematocrit, glucose, thyroid, renal, hepatic functions, electrolytes, serum and urine osmolality), and repeat nasal COVID-19 RTPCR were normal. He recovered after treatment consisting of IV methylprednisolone $(1 \mathrm{~g} / \mathrm{d})$, sodium valproate $(20 \mathrm{mg} / \mathrm{kg} / \mathrm{d})$, clonazepam $(2 \mathrm{mg} / \mathrm{d})$, and levetiracetam $(2 \mathrm{~g} / \mathrm{d})$ in 1 week (video 2). Our case adds to the increasing list of novel neurologic manifestations occurring in the setting of COVID-19. . $^{23}$

\section{Study Funding}

No targeted funding reported.

\section{Disclosure}

The authors report no disclosures relevant to the manuscript. Go to Neurology.org/ $\mathrm{N}$ for full disclosures.

\section{Appendix Authors}

\begin{tabular}{lll}
\hline Name & Location & Contributions \\
\hline $\begin{array}{l}\text { Priyank } \\
\text { Bharatkumar } \\
\text { Shah, MD, DM }\end{array}$ & Privya Clinic, Ahmedabad, Gujarat, India & $\begin{array}{l}\text { Drafting/revision of the manuscript for content, } \\
\text { including medical writing for content; major role } \\
\text { in the acquisition of data; study concept or } \\
\text { design; analysis or interpretation of data }\end{array}$ \\
\hline $\begin{array}{l}\text { Soaham Dilip } \\
\text { Desai, MD, DM }\end{array}$ & $\begin{array}{l}\text { Shree Krishna Hospital and } \\
\text { Pramukhswami Medical College, } \\
\text { Karamsad, Anand, Gujarat, India }\end{array}$ & $\begin{array}{l}\text { Drafting/revision of the manuscript for content, } \\
\text { including medical writing for content; study } \\
\text { concept or design; analysis or interpretation of } \\
\text { data }\end{array}$ \\
\hline
\end{tabular}

\section{References}

1. Oh SY, Kim JS, Dieterich M. Update on opsoclonus-myoclonus syndrome in adults. J Neurol 2019;266:1541-1548.

2. Koralnik IJ, Tyler KL. COVID-19: a global threat to the nervous system. Ann Neurol 2020;88:1-11.

3. Ellul MA, Benjamin L, Singh B, et al. Neurological associations of COVID-19. Lancet Neurol 2020;19:767-783.

\author{
Correspondence \\ Dr. Desai \\ drsoahamdesai@yahoo.com
}

\section{MORE ONLINE}

$\checkmark$ Videos

\section{COVID-19 Resources}

For the latest articles, invited commentaries, and blogs from physicians around the world

NPub.org/COVID19 


\section{Neurology}

\section{Opsoclonus Myoclonus Ataxia Syndrome in the Setting of COVID-19 Infection}

Priyank Bharatkumar Shah and Soaham Dilip Desai

Neurology 2021;96;33 Published Online before print October 1, 2020

DOI 10.1212/WNL.0000000000010978

This information is current as of October 1, 2020

Updated Information \&

Services

References

Subspecialty Collections

Permissions \& Licensing

Reprints including high resolution figures, can be found at:

http://n.neurology.org/content/96/1/33.full

This article cites 3 articles, 0 of which you can access for free at: http://n.neurology.org/content/96/1/33.full\#ref-list-1

This article, along with others on similar topics, appears in the following collection(s):

All Infections

http://n.neurology.org/cgi/collection/all_infections

All Movement Disorders

http://n.neurology.org/cgi/collection/all_movement_disorders

Clinical neurology examination

http://n.neurology.org/cgi/collection/clinical_neurology_examination Myoclonus

http://n.neurology.org/cgi/collection/myoclonus

Information about reproducing this article in parts (figures,tables) or in its entirety can be found online at:

http://www.neurology.org/about/about_the_journal\#permissions

Information about ordering reprints can be found online:

http://n.neurology.org/subscribers/advertise

Neurology ${ }^{\circledR}$ is the official journal of the American Academy of Neurology. Published continuously since 1951, it is now a weekly with 48 issues per year. Copyright () 2020 American Academy of Neurology. All rights reserved. Print ISSN: 0028-3878. Online ISSN: 1526-632X.

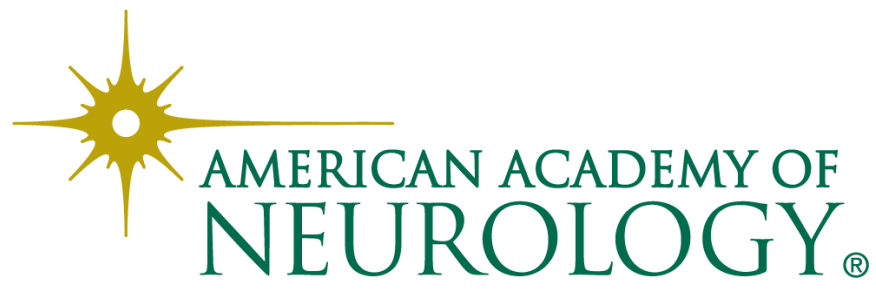

